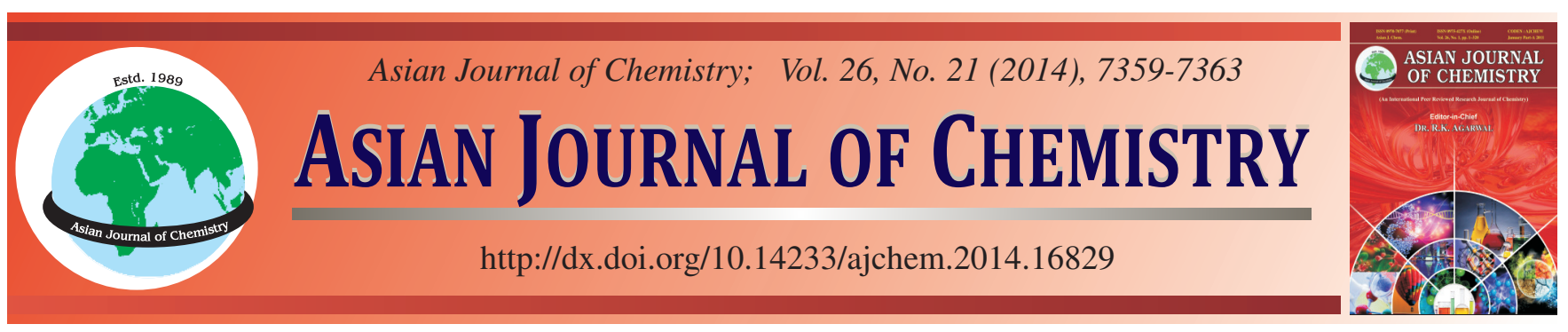

\title{
Effect of Environmental Factors on Biological Reduction of Hexavalent Chromium by Pseudomonas mendocina $\dagger$
}

\author{
G. Dogan ${ }^{1}$, N.M. Dogan ${ }^{1}$ and G.A. Doganli, ${ }^{2, *}$
}

${ }^{1}$ Biology Department, Faculty of Science and Arts, Pamukkale University, Denizli, Turkey

${ }^{2}$ Tavas Vocational High School, Pamukkale University, Denizli, Turkey

*Corresponding author: Fax: +90 258 6131119; Tel: +90 258 6131100; E-mail: gulumseracar@ pau.edu.tr

\begin{abstract}
In this study, the effects of $\mathrm{pH}$, initial chromium concentrations, organic acids (alginic acid, galacturonic acid, glucuronic acid and citric acid) and their binary combinations on the bacterial chromium reduction were investigated. The results revealed that the $\mathrm{Cr}(\mathrm{VI}) \mathrm{reduction}$ for Pseudomonas mendocina was high at optimum $\mathrm{pH}$ value (6). The $\mathrm{Cr}(\mathrm{VI})$ reduction rate of $P$. mendocina decreased with the increase in initial chromium concentration. The $\mathrm{Cr}(\mathrm{VI})$ reduction ability of the bacterium increased in the presence of organic acids especially galactronic acid and glucuronic acid. Binary combinations of galactronic acid and glucuronic acid caused a dramatic increase in the rate of chromate reduction. Experiments with heat-inactivated cells indicated that biosorption onto cell material had a negligible impact for the loss of $\mathrm{Cr}(\mathrm{VI})$ from the solution. As a result of SDS-PAGE analysis, it was observed a protein band approximately $31 \mathrm{kDa}$ in periplasmic extracts of $P$. mendocina cells.
\end{abstract}

Keywords: Biosorption, Biodegradation, Bioremediation, Chromate reduction, Electrophoresis, Pseudomonas.

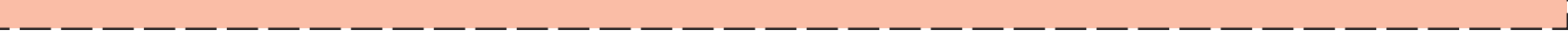

\section{INTRODUCTION}

Hexavalent chromium has been commonly used in the steel, refractory, leather tanning, wood treatment, pigment and chemical industries ${ }^{1}$. During the last few decades the uncontrolled release of industrial wastes has contaminated the soil and water with $\mathrm{Cr}(\mathrm{VI})$ throughout the world ${ }^{2-5}$.

Hexavalent chromium is a strong oxidizing species with toxic and carcinogenic influences on all living organisms, including human. Contact with $\mathrm{Cr}$ (VI) compounds over a prolonged period of time is a risk factor for developing lung cancer ${ }^{6}$. Trivalent chromium $\mathrm{Cr}$ (III) is a common representative of chromium compounds and less harmful compared to $\mathrm{Cr}(\mathrm{VI})^{7}$. Moreover, $\mathrm{Cr}(\mathrm{VI})$ penetrates into the cells via the sulfate transporters due to its structural and electrical similarity with sulfate ions, whereas, intracellular penetration of $\mathrm{Cr}$ (III) is rather not possible ${ }^{8}$.

Generally $\mathrm{Cr}(\mathrm{VI})$ is much more mobile in soil than $\mathrm{Cr}(\mathrm{III})$. The major Cr(VI) species include; chromate, bichromate and dichromate are thermodynamically stable over a large $\mathrm{pH}$ range in the environment and hardly absorbed onto soil colloids under alkaline to sub-neutral conditions. Therefore, $\mathrm{Cr}(\mathrm{VI})$ posing a threat to surface and groundwater quality ${ }^{9,10}$. Batch sorption studies, primarily performed with pure mineral phases, suggest that $\mathrm{Cr}$ (III) is highly reactive and may strongly sorb to the mineral phases ${ }^{11}$. Chromium(VI) exhibits weak to medium binding affinity for metal oxides such as $\mathrm{Fe}$ - and Al-oxides depending on the environmental conditions ${ }^{12-14}$. One of the most important factors affecting chromium mobility in underground systems is natural organic substances that are abundant in soil and water. These organic substances act as electron donors and convert $\mathrm{Cr}(\mathrm{VI})$ compounds to $\mathrm{Cr}$ (III) compounds.

Conventional methods like chemical procedures, used for the removal of hexavalent $\mathrm{Cr}$ are expensive and lack specificity ${ }^{15}$. As an alternative, biological approaches by utilizing microorganisms have the potential to remove toxic metals selectively and with considerable operational flexibility. Hence they can be used in a range of bioreactor configurations both in situ and $e x$ situ $^{16,17}$. Therefore, bacterial bioremediation is of considerable interest as an environment friendly and affordable solution to chromate pollution ${ }^{4}$. Chromium remediation studies have been carried out with several bacteria, such as Pseudomonas $^{18}$, Bacillus $^{19}$, Providencia $^{20}$ and Achromobacter ${ }^{21}$.

In this background the present study was designed to understand the effect of environmental factors such as different organic acids and their binary combinations, $\mathrm{pH}$ level and 
$\mathrm{Cr}(\mathrm{VI})$ concentration on the microbial $\mathrm{Cr}(\mathrm{VI})$ reduction by Pseudomonas mendocina bacterium. Furthermore, the biosorption of chromium was determined by dead $P$. mendocina cells and chromate reductase enzyme induction of periplasmic extracts of $P$. mendocina bacterium.

\section{EXPERIMENTAL}

Unless otherwise stated, all chemicals used in the experiments were reagent grade. Water for all experiments was supplied from a Human Power-Pure water system (Zeener Power, Korea). The stock solution of $\mathrm{Cr}(\mathrm{VI})$ was prepared by dissolving 2.829 $\mathrm{g} \mathrm{K}_{2} \mathrm{Cr}_{2} \mathrm{O}_{7}(294.19 \mathrm{~g} / \mathrm{mol})$ (Merck) in $1 \mathrm{~L} \mathrm{UV}$-water, which was autoclaved separately and added to the media before the start of experiments. The $\mathrm{D}(+)$-glucuronic acid sodium salt monohydrate $\left(\mathrm{C}_{6} \mathrm{H}_{9} \mathrm{NaO}_{7} \mathrm{H}_{2} \mathrm{O}\right)$ (Merck), $\mathrm{D}(+)$-galacturonic acid monohydrate $\left(\mathrm{C}_{6} \mathrm{H}_{10} \mathrm{O}_{7} \mathrm{H}_{2} \mathrm{O}\right)$ (Sigma-Aldrich), alginic acid sodium salt monohydrate (Sigma-Aldrich) and citric acid monohydrate $\left(\mathrm{C}_{6} \mathrm{H}_{8} \mathrm{O}_{7} \mathrm{H}_{2} \mathrm{O}\right)$ (Merck) were used as organic acids (ligands) in all the experiments. In addition, diphenylcarbazide (Merck) reagent was prepared in acetone. All stock solutions were stored in amber glass bottles in darkness at $4{ }^{\circ} \mathrm{C}$.

Culture conditions of microorganism: The waste water isolates of Pseudomonas mendocina used in this study were obtained from Bacteriology Labrotory Culture Collection, Department of Biology, Pamukkale University. To determine the best chromium reduction medium, three different medium were used such as, Nutrient Broth (NB; g/L: peptone 5, yeast extract 2 , meat extract 1 , sodium chloride 5), triptic soy broth (TSB; g/L: pepton from casein, 17, pepton from soy meal 3, $\mathrm{D}(+)$-glucose 2.5 , sodium chloride 5 , di-potassium hydrogen phosphate 2.5) and Lauri Bertani-Miller (LB-Miller; g/L: tripton 10 , yeast extract 5 , sodium chloride 10 ). All media were autoclaved at $121^{\circ} \mathrm{C}$ for $15 \mathrm{~min}$ and stored at $4{ }^{\circ} \mathrm{C}$ until use.

Chromium-resistance evaluation of bacterial strain: The minimum inhibitory concentration (MIC) of $\mathrm{Cr}(\mathrm{VI})$ resistant strain was determined by broth dilution method ${ }^{22}$ in triptic soy broth medium with $\mathrm{Cr}(\mathrm{VI})$ concentrations ranging from 10 to $500 \mathrm{mg} / \mathrm{L}$. The bacterium samples $(2 \%)$ were inoculated to this series and incubated at $37^{\circ} \mathrm{C}$. After $24 \mathrm{~h}$, tube series were checked. The minimum concentration of chromium in the medium inhibiting complete growth was taken as the minimal inhibitory concentration (MIC). minimal inhibitory concentration experiments were performed triplicate.

Reduction of $\mathbf{C r}(\mathbf{V I})$ : The $250 \mathrm{~mL}$ flasks containing 100 $\mathrm{mL}$ of triptic soy broth with a desired concentration of $\mathrm{Cr}(\mathrm{VI})$ were inoculated with $2 \mathrm{~mL}$ cultures of Pseudomonas mendocina at logarithmic phase. The initial $\mathrm{pH}$ of the media was adjusted to $7( \pm 0.2)$ using an appropriate amount of $\mathrm{NaHCO}_{3}(0.11$ $\mathrm{mM})$. All media were autoclaved at $121^{\circ} \mathrm{C}$ for $15 \mathrm{~min}$ before use in microbial $\mathrm{Cr}(\mathrm{VI})$ reduction experiments. Cultures were then incubated at $37{ }^{\circ} \mathrm{C}$ with constant shaking at $125 \mathrm{rpm}$. Immediately after inoculation with bacteria, samples were drawn at regular time intervals (every $12 \mathrm{~h}$ ) and centrifuged at $6000 \mathrm{rpm}$ for $20 \mathrm{~min}$. The concentration of $\mathrm{Cr}(\mathrm{VI})$ in the supernatant was determined colorimetrically using diphenylcarbazide reagent at $540 \mathrm{~nm}$ by UV spectrophotometer ${ }^{23}$. The growth of cells was also routinely monitored by measuring optical density (OD) at $600 \mathrm{~nm}$. The experiments were carried out in duplicate.
Effects of different $\mathrm{pH}$ levels on bacterial chromium reduction: In order to specify effects of $\mathrm{pH}$ to bacterial $\mathrm{Cr}(\mathrm{VI})$ reduction, triptic soy broth mediums containing $25 \mathrm{mg} / \mathrm{L}$ $\mathrm{Cr}(\mathrm{VI})$ were prepared at different $\mathrm{pH}$ series such as, 6, 7, 7.5, 8, 9. To stabilize the $\mathrm{pH}, \mathrm{NaHCO}_{3}$ buffer was used for $\mathrm{pH} 6,7$, 7.5 and 8 and $\mathrm{NH}_{3}-\mathrm{NH}_{4} \mathrm{Cl}$ buffer was used for 9 . Then mediums were autoclaved at $121^{\circ} \mathrm{C}$ for $15 \mathrm{~min}$. The bacterium samples ( $2 \%$ ) were inoculated to this series media.

Effects of initial chromium concentration on bacterial chromium reduction: To identify effects of different chromium concentrations, triptic soy broth mediums of different initial chromium concentrations such as, 10, 15, 20 and $25 \mathrm{mg} / \mathrm{L}$ for the bacterium were prepared. The media were autoclaved at $121{ }^{\circ} \mathrm{C}$ for $15 \mathrm{~min}$. The bacterium samples $(2 \%)$ were then inoculated to this series.

Effects of organic acids and their binary interactions to bacterial chromium reduction: The effect of organic acids and their binary interactions on the bacterial chromium reduction were investigated by using alginic acid, galacturonic acid, glucuronic acid and citric acid as electron donors. Organic molecules were added for each of them as $1 \mathrm{~g} / \mathrm{L}$.

Biosorption: $P$. mendocina bacteria, after being incubated for $24 \mathrm{~h}$ in $1000 \mathrm{~mL}$ triptic soy broth medium, were centrifuged at $6000 \mathrm{rpm}$ at $+4{ }^{\circ} \mathrm{C}$ for $20 \mathrm{~min}$. The obtained pellets were dried under aseptic conditions for $12-16 \mathrm{~h}$ at $80^{\circ} \mathrm{C}$. After that, heat killed cells were used as a biosorbent in the biosorption experiments. The biosorbents with the final concentration of $1 \mathrm{~g}$ cell/L were suspended in $100 \mathrm{~mL}$ of the chromium solution $(10,15,20$ and $25 \mathrm{mg} / \mathrm{L})$. The samples were incubated at $37^{\circ} \mathrm{C}$ and their chromium concentration was periodically determined according to diphenylcarbazide method.

Chromate reductase enzyme induction: For analysis of chromate reductase enzyme induction of $P$. mendocina bacterium, it was grown in media containing 10 and $15 \mathrm{mg} / \mathrm{L} \mathrm{Cr}$ (VI) and without $\mathrm{Cr}$ (VI) (control) at $37^{\circ} \mathrm{C}$ for $24 \mathrm{~h}$ with constant shaking at $125 \mathrm{rpm}$. Then, to determine the existence of induced chromium reductase, osmotic shock method was used by obtaining periplasmic fractions from overnight grown bacteria for all of chromium concentrations ${ }^{24,25}$. In order to compare the protein profiles of the periplasmic fractions of the cells grown with and without chromate, the concentrated periplasmic fractions were suspended in $100 \mu \mathrm{L}$ of $1 \mathrm{x}$ cracking buffer $(0,0625$ $\mathrm{M}$ tris- $\mathrm{HCl}, \mathrm{pH} 6.8 ; 2 \%$ SDS, $10 \%$ glycerol, $5 \% \beta$-mercaptoethanol and $0,001 \%$ bromophenol blue) and mixed thoroughly by vortexing for 1-2 min. The lyzed suspensions were then boiled and loaded on $10 \%$ SDS-PAGE ${ }^{26}$. Proteins were resolved by electrophoresis at $100 \mathrm{~V}$ for $2 \mathrm{~h}$ (stacking) and $200 \mathrm{~V}$ for $4 \mathrm{~h}$ (resolving). Gels were stained with coomassie brilliant blue R-250.

\section{RESULTS AND DISCUSSION}

It is well known that hexavalent chromium is toxic to all forms of life including humans and exhibits mutagenic, teratogenic and carcinogenic effects on biological systems due to its strong oxidizing nature ${ }^{27}$. Therefore, the concentration of $\mathrm{Cr}(\mathrm{VI})$ in the effluents before discharging in environment needs to be reduced to the permissible limit $(e . g .,<0.05 \mathrm{mg} / \mathrm{L}$ as per US-EPA $)^{28}$ by using appropriate technology. The ability 
of some bacteria to reduce $\mathrm{Cr}(\mathrm{VI})$ has raised the possibility of using these microorganisms as a biotechnological tool for bioremediation of chromium-polluted zones ${ }^{29,30}$. Bioremediation of $\mathrm{Cr}(\mathrm{VI})$ using $\mathrm{Cr}$-resistant bacteria provides a safe, effective and alternative viable process ${ }^{31}$. Bacterial chromium reduction is affected by multiple factors such as $\mathrm{pH}$, chromium concentration, carbon sources, natural organic acids, metal ions and temperature.

Chromium resistance evaluation of bacterial strain: The study made to determine the medium showed that the best medium for the Pseudomonas mendocina growth and rapid $\mathrm{Cr}(\mathrm{VI})$ reduction was triptic soy broth medium. All the experiments were then carried out at $37^{\circ} \mathrm{C}$, in triptic soy broth medium. The chromium-resistance of the bacterium was determined by identifying the minimum inhibition concentration using the broth dilution method. While applying the broth dilution method, chromium concentration was kept at $10-500 \mathrm{mg} / \mathrm{L}$ and the overall volume was $5 \mathrm{~mL}$. The minimum concentration of the dilution tube where there was not an observable growth was taken as MIC. Moreover, the results were verified by inoculating petri dish and we found $25 \mathrm{mg} / \mathrm{L}$ MIC value for the bacterium.

Effects of pH: The initial $\mathrm{pH}$ of the culture plays a crucial role in chromium reduction. Many researchers have investigated the optimum $\mathrm{pH}$ values for chromium reduction through bacteria. Wang and $\mathrm{Xiao}^{32}$ reported that, the optimum $\mathrm{pH}$ value for reduction of chromium by Bacillus sp. and Pseudomonas fluorescens is 7 and chromium reduction is inhibited at $\mathrm{pH} 6$. On the other hand, it was found that optimum initial $\mathrm{pH}$ was 9 for another Bacillus sp. XW4 isolate and one Gram-positive isolate ${ }^{33}$. The variation observed in optimal $\mathrm{pH}$ indicates that it is important to determine the optimum $\mathrm{pH}$ value in different cultures and to modify the $\mathrm{pH}$ in order to achieve maximum $\mathrm{Cr}(\mathrm{VI})$ reduction of chromium detoxification. Therefore, the effect of $\mathrm{pH}$ variation on $\mathrm{Cr}(\mathrm{VI})$ at $\mathrm{pH}$ levels of $6,7,7.5,8$ and 9 was assessed in the present study. It was found that the optimum $\mathrm{pH}$ value was 6 and all $25 \mathrm{mg} / \mathrm{L} \mathrm{Cr}(\mathrm{VI})$ was reduced at $36^{\text {th }} \mathrm{h}$. Therefore, other chromium reduction experiments were performed at $\mathrm{pH} 6$. At $\mathrm{pH} 7,7.5$ and 8 the chromium reduction was very similar and it completely reduced at $48^{\text {th }} \mathrm{h}$ of incubation at $\mathrm{pH} 7$ and 7.5 whereas, at $\mathrm{pH} 8$, reduction was slightly slow and completed at the $60^{\text {th }} \mathrm{h}$. However, at $\mathrm{pH} 9$, there was very limited $\mathrm{Cr}(\mathrm{VI})$ reduction. The effect of $\mathrm{pH}$ on chromium reduction in growth media is shown in Fig. 1. The general trend with reference to the influence of $\mathrm{pH}$ on reduction was $\mathrm{pH} 6>\mathrm{pH} 7=\mathrm{pH} 7.5>\mathrm{pH} 8>\mathrm{pH} 9$ (Fig. 1).

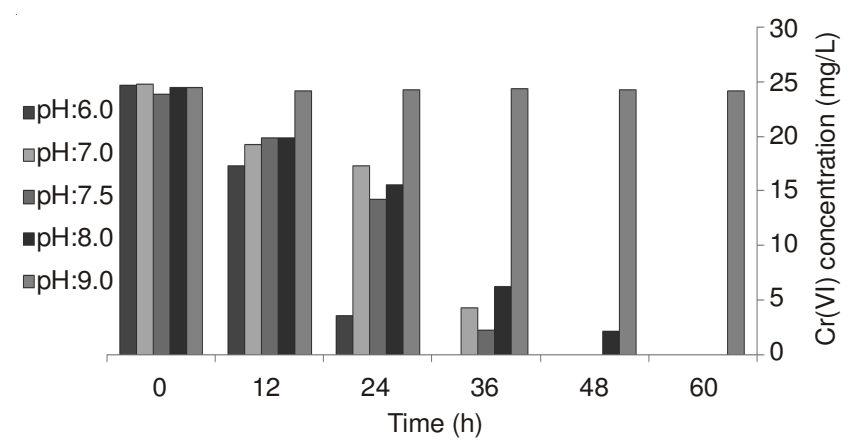

Fig. 1. Effect of different $\mathrm{pH}$ levels on $\mathrm{Cr}(\mathrm{VI})$ reduction by $P$. mendocina with $25 \mathrm{mg} / \mathrm{L} \mathrm{Cr}(\mathrm{VI})$ in triptic soy broth media
Effects of initial chromium concentration: The effect of initial $\mathrm{Cr}(\mathrm{VI})$ concentration on $\mathrm{Cr}(\mathrm{VI})$ reduction by using four different $\mathrm{Cr}(\mathrm{VI})$ concentrations $(10,15,20,25 \mathrm{mg} / \mathrm{L})$ has been shown in Fig. 2. The complete $\mathrm{Cr}(\mathrm{VI})$ reduction was observed for all concentration at $36 \mathrm{~h}$. At the first $24 \mathrm{~h}$ of incubation, $\mathrm{Cr}(\mathrm{VI})$ reduction rates of $P$. mendocina bacterium in media containing 10, 15, 20 and $25 \mathrm{mg} / \mathrm{L} \mathrm{Cr}(\mathrm{VI})$ were 76.29 , $66.45,51,19$ and $44.13 \%$, respectively. A similar trend was also observed in Pannonibacter phragmitetus LSSE-09 ${ }^{34}$ and Ochrobactrum $\mathrm{sp}^{35}$. The decrease in chromate reduction rate with the increase of initial $\mathrm{Cr}(\mathrm{VI})$ concentration might be due to chromate toxicity.

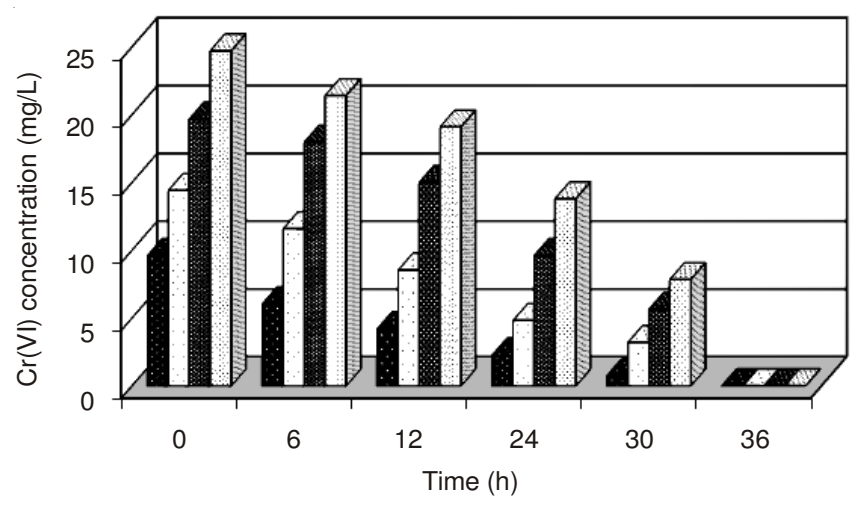

Fig. 2. Effect of initial $\mathrm{Cr}(\mathrm{VI})$ concentrations on chromate reduction in triptic soy broth media

Effects of organic acids and their binary interactions: The effects of organic acids such as galacturonic acid, glucuronic acid, alginic acid and citric acid on $\mathrm{Cr}(\mathrm{VI})$ reduction by Pseudomonas mendocina was tested at 10, 15, 20 and $25 \mathrm{mg} / \mathrm{L}$ $\mathrm{Cr}$ (VI) containing medium (Fig. 3a-d). Among the organic acids used in the study, galactronic acid and/or glucuronic acid was the most effective on $\mathrm{Cr}$ (VI) reduction. Other organic acids (alginic acid and citric acid) were not affected the chromium reduction of $P$. mendocina bacterium considerably. At 10, 15, 20 and $25 \mathrm{mg} / \mathrm{L} \mathrm{Cr}(\mathrm{VI})$ concentration, complete $\mathrm{Cr}(\mathrm{VI})$ reduction was observed in the control (without organic acids) at $36 \mathrm{~h}$. However, when galactronic acid or glucuronic acid was added in growth medium, $\mathrm{Cr}(\mathrm{VI})$ reduction completed at $30 \mathrm{~h}$ for 20 and $25 \mathrm{mg} / \mathrm{L} \mathrm{Cr}(\mathrm{VI})$ and $12 \mathrm{~h}$ for 10 and $15 \mathrm{mg} / \mathrm{L}$ $\mathrm{Cr}(\mathrm{VI})$. This might be due to actual organic acids which serve as an electron donor. Previous studies on $\mathrm{Cr}(\mathrm{VI})$ reduction by Pseudomonas putida P18 and Pseudomonas aeruginosa P16 showed that the glucuronic acid, galactronic acid, alginic acid and bacterial EPS were used as organic ligand and reduction was faster in the medium containing these organic acids. Furthermore, the influence trend of these organic acids was alginic acid $>$ glucuronic acid $>$ EPS $>$ galactronic acid ${ }^{18}$. Desai et al ${ }^{36}$ observed an enhanced chromate reductase activity by Pseudomonas sp. G1DM21 in the presence of electron donors such as citrate, acetate and succinate.

In natural media such as soil and water, these kinds of organic compounds undoubtedly exist together and interact with each other. The presents study therefore used the binary combinations of natural organic acids and determined the relationship between these combinations and $\mathrm{Cr}(\mathrm{VI})$ reduction. The results showed that there are synergistic effect between 

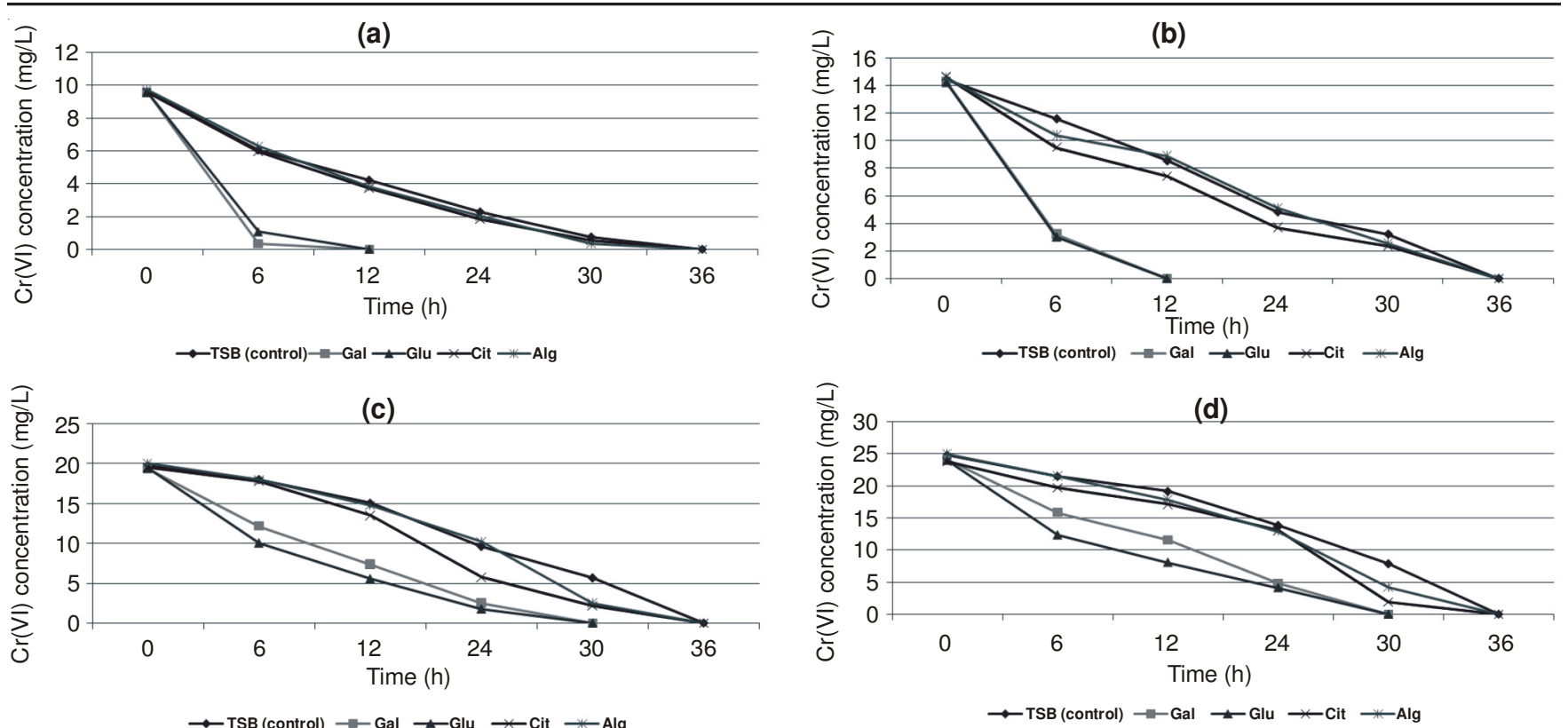

Fig. 3. Effect of different organic acids $(1 \mathrm{~g} / \mathrm{L})$ on $\mathrm{Cr}(\mathrm{VI})$ reduction by $P$. mendocina Gal: galactronic acid, glu: glucuronic acid, cit: citric acid, alg: alginic acid, (a) $10 \mathrm{mg} / \mathrm{L} \mathrm{Cr}(\mathrm{VI})$ containing media, (b) $15 \mathrm{mg} / \mathrm{L} \mathrm{Cr}(\mathrm{VI})$ containing media, (c) $20 \mathrm{mg} / \mathrm{L} \mathrm{Cr}$ (VI) containing media, (d) $25 \mathrm{mg} / \mathrm{L} \mathrm{Cr}(\mathrm{VI})$ containing media

galactronic acid and glucuronic acid, galactronic acid and citric acid, glucuronic acid and citric acid, glucuronic acid and alginic acid combinations (Fig. 4). Using this combinations, the $\mathrm{Cr}(\mathrm{VI})$ reduction time was decreased and it was approximately half, compared to separate use of organic acids. The reduction time for $25 \mathrm{mg} / \mathrm{L} \mathrm{Cr}(\mathrm{VI})$ is $12 \mathrm{hr}$ in binary combinations of galactronic acid and glucuronic acid (30 h for one by one) (Fig. 4). On the other hand, binary combination of galactronic acid and alginic acid did not affect the $\mathrm{Cr}(\mathrm{VI})$ reduction time significantly. Interestingly, alginic acid and citric acid combination extended the $\mathrm{Cr}(\mathrm{VI})$ reduction time from 36 to $54 \mathrm{~h}$. There is very scanty information published regarding the binary combinations of organic acids for $\mathrm{Cr}(\mathrm{VI})$ reduction ${ }^{37,38}$.

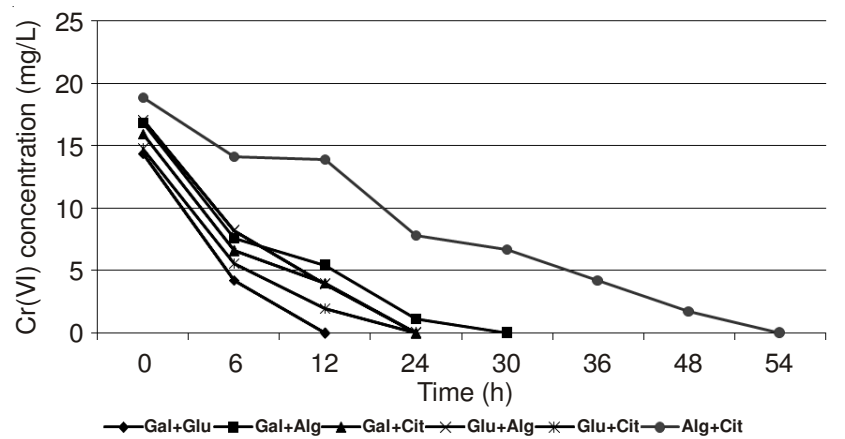

Fig. 4. Effect of binary combinations of organic acids with $25 \mathrm{mg} / \mathrm{L} \mathrm{Cr}$ (VI) on chromium reduction by P. mendocina Gal: galactronic acid, glu: glucuronic acid, cit: citric acid, alg: alginic acid

Biosorption: Experiments with heat-inactivated cells indicated that biosorption of cell material had a negligible impact for the loss of $\mathrm{Cr}(\mathrm{VI})$ from solution (Fig. 5). In the heat killed cells of $P$. mendocina bacterium biosorped only $1.33,1.84,4.82$ and $0.95 \%$ in $25,20,15$ and $10 \mathrm{mg} / \mathrm{L} \mathrm{Cr}(\mathrm{VI})$ solution, respectively at $60^{\text {th }} \mathrm{h}$ of incubation. After the $60 \mathrm{~h}$ of incubation biosorption stopped and chromium concentration was stabilized.

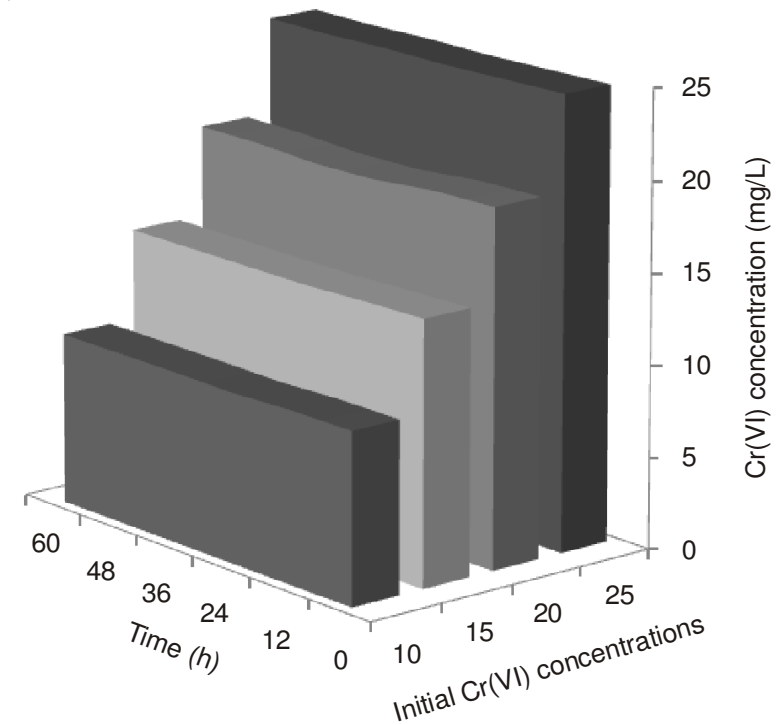

Fig. 5. Biosorption of different initial $\mathrm{Cr}(\mathrm{VI})$ concentrations by heatinactivated cells of $P$. mendocina

Chromate reductase enzyme induction: Chromate reduction by bacteria occurs under aerobic or anaerobic conditions and it has been associated with soluble or membraneassociated enzyme activities ${ }^{27,39}$. It was determined by various methods such as SDS-PAGE, NMR and MS that induced of chromate reductase at the presence of chromium in growth medium of bacteria. In the present investigation a protein that has a molecular weight around $31 \mathrm{kDa}$ was induced in the presence of chromium (15 mg/L) (Fig. 6). Similar types of protein induction studies have been done and chromate reductase has been purified from $P$. putida MK1 which has a molecular weight of $20 \mathrm{kDa}$ on SDS-PAGE ${ }^{40}$. Similarly, in $P$. aeruginos $a^{24}$ and Ochrobactrum $\mathrm{sp}^{34}$ chromate reductase was shown to have a molecular weight of $30 \mathrm{kDa}$. In another study, it was reported that the presence of an induced protein having 


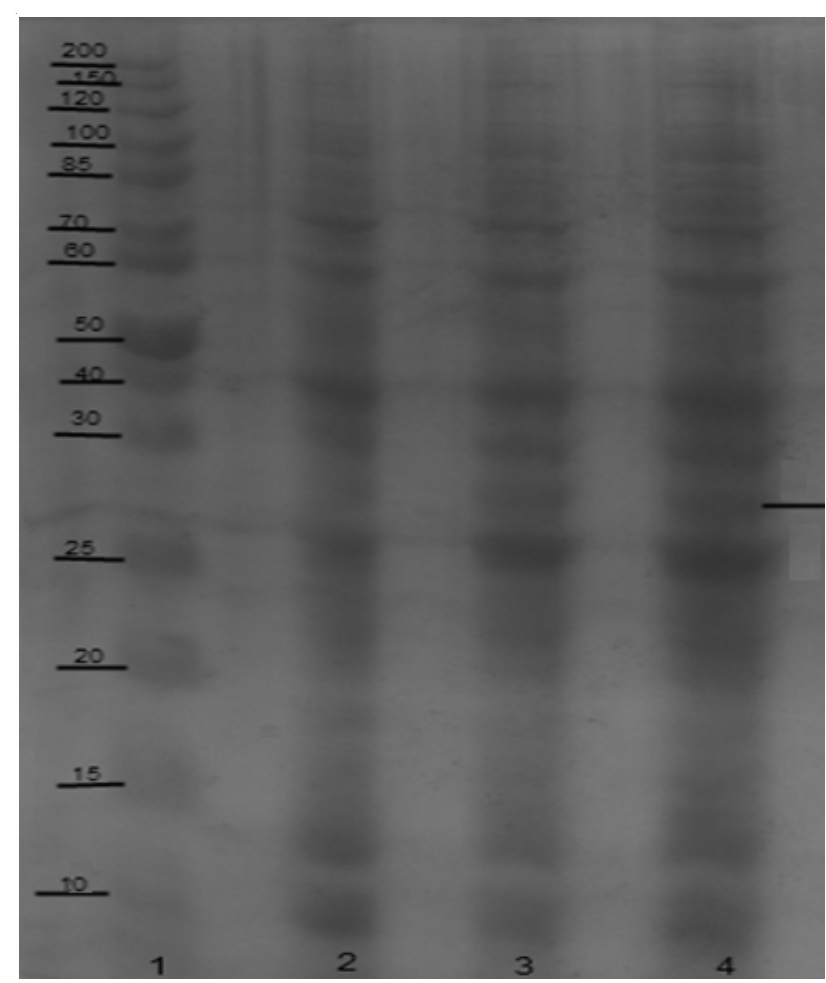

Fig. 6. Comparison of periplasmic protein profiles of P. mendocina 1: Marker (SM-0661), 2: without chromium, 3: with $10 \mathrm{mg} / \mathrm{L} \mathrm{Cr}$ (VI), 4: with $15 \mathrm{mg} / \mathrm{L} \mathrm{Cr}$ (VI)

molecular weight around $25 \mathrm{kDa}$ in the presence of chromium in Bacillus sp. JDM-2-1 and Staphylococcus capitis bacteria ${ }^{41}$.

\section{Conclusion}

The use of microorganisms for detoxification of environment contaminated with $\mathrm{Cr}(\mathrm{VI})$ has received considerable attention in recent years, because of their ability to tolerate and reduce $\mathrm{Cr}(\mathrm{VI})$. The effects of environmental factors $(\mathrm{pH}$, organic compounds and their combinations, Cr concentration) on $\mathrm{Cr}(\mathrm{VI})$ reduction to achieve maximum reduction by the Pseudomonas mendocina strain has been reported. It has been found that galactronic acid and/or glucuronic acid are the most effective organic acids which can be used for $\mathrm{Cr}(\mathrm{VI})$ reduction. The optimum $\mathrm{pH}$ was 6 and initial chromium concentration has negative effect on bacterial chromium reduction. Also we determined the $\mathrm{Cr}(\mathrm{VI})$ was not biosorped onto cell surface by $P$. mendocina bacterium. Additionally, we detected a protein that has a molecular weight around $31 \mathrm{kDa}$ by SDS-PAGE. The presence of this protein in the periplasmic extracts of cells grown in the presence of chromate, but its absence of the protein in cells grown without chromate, points out a possible role of this protein in chromate reduction.

\section{ACKNOWLEDGEMENTS}

This study was supported by the Scientific Research Council of Pamukkale University, Turkey (Research Grant 2010FBE049).

\section{REFERENCES}

1. X.R. Xu, H.B. Li, X.Y. Li and J.D. Gu, Chemosphere, 57, 609 (2004).

2. R. Milacic and J. Stupar, Environ. Sci. Technol., 29, 506 (1995).

3. B. Chattopadhyay, S. Datta, A. Chattergi and S.K. Mukhopadhyay, J. Soc. Leather Technol. Chem., 84, 94 (1999).

4. D.F. Ackerley, Y. Barak, S.V. Lynch, J. Curtin and A. Matin, J. Bacteriol., 188, 3371 (2006)

5. J.W. Yang, Z.S. Tang, R.F. Guo and S.Q. Chen, Environ. Prog., 27, 302 (2008).

6. K. Salnikow and A. Zhitkovich, Chem. Res. Toxicol., 21, 28 (2008).

7. Nickel and Welding, In: IARC Monographs on the Evaluation of Carcinogenic Risks to Humans, IARC, Lyon, France, Vol. 49 (1990).

8. Y. Pereira, G. Lagniel, E. Godat, P. Baudouin-Cornu, C. Junot and J. Labarre, Toxicol. Sci., 106, 400 (2008).

9. C.S. Uyguner and M. Bekbolet, Appl. Catal. B, 49, 267 (2004).

10. L. Leita, A. Margon, A. Pastrello, I. Arcon, M. Contin and D. Mosetti, Environ. Pollut., 157, 1862 (2009).

11. M.A. Mayes, P.M. Jardine, I.L. Larsen, S.C. Brooks and S.E. Fendorf, J. Contam. Hydrol., 45, 243 (2000).

12. J.M. Zachara, D.C. Girvin, R.L. Schmidt and C.T. Resch, Environ. Sci. Technol., 21, 589 (1987).

13. K. Mesuere and W. Fish, Environ. Sci. Technol., 26, 2357 (1992).

14. R. Weerasooriya and H.J. Tobschall, Colloids Surf. A, 162, 167 (2000).

15. S.K. Katiyar and R. Katiyar, Adv. Microbiol. Biotechnol., 19, 330 (1997).

16. D.R. Lovley and J.D. Coates, Curr. Opin. Biotechnol., 8, 285 (1997).

17. J.R. Lloyd and D.R. Lovley, Curr. Trends Biotechnol., 12, 248 (2001).

18. N.M. Dogan, C. Kantar, S. Gulcan, C.J. Dodge, B.C. Yilmaz and M.A. Mazmanci, Environ. Sci. Technol., 45, 2278 (2011).

19. P. Pillai and G. Archana, Process Biochem., 47, 2116 (2012).

20. U. Thacker, R. Parikh, Y. Shouche and D. Madamwar, Process Biochem., 41, 1332 (2006).

21. W. Zhu, L. Chai, Z. Ma, Y. Wang, H. Xiao and K. Zhao, Microbiol. Res., 163, 616 (2008).

22. J.J. Calomoris, T.L. Armstrong and R.J. Seidler, Appl. Environ. Microbiol., 47, 1238 (1984).

23. American Public Health Association (APHA), Standard Methods for the Examinations of Water and Wastewater, Washington, DC, USA, edn. 19 (1995)

24. K. Poole and R.E.W. Hancock, Eur. J. Biochem., 144, 607 (1984).

25. A. Ganguli and A.K. Tripathi, J. Microbiol. Biotechnol., 11, 355 (2001).

26. U.K. Laemmli, Nature, 227, 680 (1970).

27. K.H. Cheung and J.D. Gu, Int. Biodeterior. Biodegrad., 59, 8 (2007).

28. Environmental Protection Agency (EPA), Toxicological Review of Hexavalent Chromium, Washington DC, USA, CASNR, 18540-29-9, (1998).

29. P. Wang, T. Mori, K. Komori, K. Sasatsu, K. Toda and H. Ohtake, Appl. Environ. Microbiol., 55, 1665 (1989).

30. T. Wakatsuki, J. Ind. Microbiol., 14, 169 (1995).

31. H.J. Bai, Z.M. Zhang, G.E. Yang and B.Z. Li, Bioresour. Technol., 99, 7716 (2008).

32. Y.-T. Wang and C. Xiao, Water Res., 29, 2467 (1995).

33. Y.G. Liu, W.H. Xu, G.M. Zeng, X. Li and H. Gao, Process Biochem., 41, 1981 (2006).

34. L. Xu, M. Luo, W. Li, X. Wei, K. Xie, L. Liu, C. Jiang and H. Liu, J. Hazard. Mater., 185, 1169 (2011).

35. U. Thacker and D. Madamwar, World J. Microbiol. Biotechnol., 21, 891 (2005)

36. C. Desai, K. Jain and D. Madamwar, Process Biochem., 43, 713 (2008).

37. G. Acar, N.M. Dogan, E. Evgen and G. Dogan, Curr Opin Biotechnol., 22S, S69 (2011).

38. G.A. Doganli and N.M. Dogan, Desalin. Water Treat., doi:10.1080/ 19443994.2013.823117.

39. T. Suzuki, N. Miyata, H. Horitsu, K. Kawai, K. Takamizawa, Y. Tai and M. Okazaki, J. Bacteriol., 174, 5340 (1992).

40. C.H. Park, M. Keyhan, B. Wielinga, S. Fendorf and A. Matin, Appl. Environ. Microbiol., 66, 1788 (2000).

41. A. Zahoor and A. Rehman, J. Environ. Sci. (China), 21, 814 (2009). 